Research article

\title{
CARDIAC TROPONIN-I CONCENTRATION IN WEANED CALVES WITH BOVINE RESPIRATORY DISEASE
}

\author{
HANEDAN Basak ${ }^{*}$, KIRBAS Akin ${ }^{1}$, DORMAN Emrullah², TIMURKAN Mehmet \\ $\mathrm{Ozkan}^{3}$, KANDEMIR Fatih Mehmet ${ }^{4}$, ALKAN Omer ${ }^{5}$ \\ ${ }^{1}$ Department of Internal Medicine, Faculty of Veterinary Medicine, Ataturk University, Erzurum, \\ Turkey; ${ }^{2}$ Department of Biochemistry, Faculty of Medicine, Ataturk University, Erzurum, Turkey; \\ ${ }^{3}$ Department of Virology, Faculty of Veterinary Medicine, Ataturk University, Erzurum, Turkey; \\ ${ }^{4}$ Department of Biochemistry, Faculty of Veterinary Medicine, Ataturk University, Erzurum, Turkey; \\ ${ }^{5}$ Department of Econometrics, Faculty of Economics and Administrative Science, Ataturk University, \\ Erzurum, Turkey
}

(Received 25 February; Accepted 1 June 2015)

\begin{abstract}
The aim of this study was to evaluate the serum cardiac troponin I (cTnI) concentrations in weaned calves with moderate and severe bovine respiratory disease. Eighteen healthy weaned calves (group I), 18 weaned calves with moderate bovine respiratory disease (group II) and 18 weaned calves with severe bovine respiratory disease (group III) were included in the study. Clinical signs and severity of respiratory disease according to clinical index scores were determined. Blood cell counts and cardiac biomarkers, such as serum cTnI concentrations and creatine kinase-myocardial band (CK-MB), and lactate dehydrogenase (LDH) activities were determined in all groups. Temperature and respiratory and pulse rates were significantly increased in calves with moderate and severe bovine respiratory disease compared to healthy calves $(\mathrm{P}<0.05)$. Serum $\mathrm{c}$ TnI concentrations and LDH activities were significantly increased in the calves with severe bovine respiratory disease compared to healthy calves and calves with moderate bovine respiratory disease $(\mathrm{P}<0.05)$. A significant increase in white blood cell counts in calves with moderate and severe bovine respiratory disease and lymphopenia and neutrophilia in calves with severe bovine respiratory disease were also found. The study suggests that severe bovine respiratory disease causes increased serum cTnI concentrations in weaned calves.
\end{abstract}

Key words: bovine respiratory disease, cardiac biomarkers, hematologic parameters, calves.

\section{INTRODUCTION}

Bovine respiratory disease (BRD) causes important morbidity, mortality and economic losses in beef and dairy cattle [1]. BRD is caused by stress including weaning, commingling of cattle from various sources, poorly ventilated areas, overcrowding,

\footnotetext{
*Corresponding author: e-mail: fbhanedan@gmail.com
} 
environmental temperature and shipping [1,2]. BRD may also result from exposure to multiple pathogens, especially viral pathogens such as bovine herpes virus-1, bovine respiratory syncytial virus, parainfluenza-3, bovine viral diarrhea virus, adenoviruses (types 3 and 7), rhinoviruses, and coronaviruses. Bacterial pathogens such as $M$. haemolytica, P. multocida, Mycoplasma spp., H. somni, and A. pyogenes may also cause BRD $[3,4]$.

Of these pathogenic bacteria, $H$. somni has a tendency to cause heart damage, and a septic thrombus in the caudal vena cava can create bronchopneumonia and endocarditis [3]. Fever, hypoxia, septicemia, complement and coagulation initiation, increased acute phase proteins, exotoxin and endotoxin production, lung abscesses, consolidation, and vasculitis may occur in BRD [3,5-7] and could lead to myocardial injury $[3,5,6,8]$.

Cardiac troponin is a myofibrillar protein that controls contractions of the heart; it has two forms, cardiac troponin I (c'TnI) and cardiac troponin $\mathrm{T}$ (c'TnT) that are both used in the diagnosis of cardiac injury in humans and animals. As long as the cardiac injury continues, cardiac troponin concentrations remain elevated. Cardiac troponin is considered the gold standard biomarker of cardiac injury because of its high tissue specificity, diagnostic sensitivity, low basal blood concentration, rapid release, and persistence in the blood [9-12].

Troponin analyses are more sensitive and specific than creatine kinase-myocardial band (CK-MB) and lactate dehydrogenase (LDH) assays. Also, CK-MB expression is not limited to the heart and is also expressed in other tissues such as skeletal muscle and the gastrointestinal tract. Therefore, compared to CK-MB, cardiac troponin is chosen for the specific detection of cardiac injury [5]. Additionally, cTnI, not c'TnT, is the essential indicator for detecting and quantifying an active myocardial injury in cattle [11]. Several studies have reported that cardiac troponin concentrations are increased in cases of community-acquired pneumonia in humans [6], and chronic suppurative pneumonia in cattle [13].

Cardiac troponin I concentrations have been reported in various diseases in cattle [14-16] but not in BRD. Therefore, the present study was aimed to evaluate the serum cardiac troponin I concentrations in weaned calves with moderate and severe BRD.

\section{MATERIAL AND METHODS}

\section{Animals}

We used 18 healthy weaned calves (group I) and 18 weaned calves with moderate BRD (group II) and 18 weaned calves with severe BRD (group III). All calves were 4 to 8 months old. They were the Swiss Brown breed and were supplied from weaned calves housed in private farms in Erzurum province of the eastern region of Turkey. Moderate and severe respiratory disease in weaned calves was determined according to the clinical index score. 


\section{Clinical examination}

Clinical examination signs included rectal temperature, pulse and respiratory rate (per minute), cough, dyspnoea, nasal discharge, and respiratory sounds. Clinical parameters, observation grading and weighted numerical score included demeanour (normal = 2 , depressed $=4$, moribund $=8$ ); appetite (normal $=2$, depressed $=4$, anorexic $=$ 8); rectal temperature $\left(<39.5{ }^{\circ} \mathrm{C}=4,>39.5{ }^{\circ} \mathrm{C}\right.$ but $\left.<40.5{ }^{\circ} \mathrm{C}=8,>40.5{ }^{\circ} \mathrm{C}=12\right)$; respiratory rate (per minute) $(<35=3,35-50=6,>50=9)$; type of respiration (normal $=1$, dyspnoeic $=2)$; cough (absent $=1$, present $=2$ ); and nasal discharge (absent $=1$, present $=2$ ). Clinical index scores were calculated by adding up the weighted numerical scores from the animal's observation grade divided by the total weighted clinical score of 79 [17].

\section{Hematologic and biochemical assay}

Hematologic parameters including red blood cells (RBCs), haemoglobin, haematocrit values, white blood cells (WBCs), the percentages of neutrophils, lymphocytes, monocytes, eosinophils, and basophils, mean corpuscular volume (MCV), and platelets (PLT) were determined for each group. Also analyzed for each group were various cardiac biomarkers including cTnI concentrations and CK-MB and LDH activities. For analysis of the hematologic parameters and cardiac biomarkers, blood samples were collected by direct puncture of the vena jugularis of all calves into EDTA vacutainers (BD Vacutainer ${ }^{\circledR}, \mathrm{K} 2 \mathrm{E} 3.6 \mathrm{mg}, \mathrm{BD}-\mathrm{Plymouth}, \mathrm{UK}$ ) and plain tubes (Ayset ${ }^{\circledR}$ Tube, Clot Activator \& Gel (ZS), Turkey) and serum samples were stored - $20{ }^{\circ} \mathrm{C}$ until further analysis. Blood cell counts were measured with a haematology analyser specific for cattle (Abacus Junior Vet 5-Diatron $\mathrm{GmbH}$, Austria). The serum cTnI concentrations were determined by a commercial immunoassay system according to the one-step sandwich method (Unicel Beckman Coulter Access II, USA). Troponin I sequence homology between humans and cattle is $>96 \%$ [18], thus this assay may be reliably used in calves. The immunoassay system can measure troponin in a range of $0.01-100 \mathrm{ng} / \mathrm{mL}$. Serum enzymes such as CK-MB (CK IFCC method plus Immunoinhibition), LDH (L-P'a IFCC) activities were determined by a biochemistry autoanalyser (Beckman Coulter, AU5800, USA) using commercial enzyme kits.

\section{Analysis of viruses}

Nasal swap specimens obtained from all the animals were kept at $-80{ }^{\circ} \mathrm{C}$ until further analysis. In the thawed nasal swap specimens, viral nucleic acids were extracted by a viral nucleic acid extraction kit (Vivantis, Malaysia). After viral nucleic acid extraction process, nucleic acids, including RNA, the bovine respiratory syncytial virus and parainfluenza-3, were converted to complementary DNA using RevertAid First Strand cDNA Synthesis Kit (Cat No: K1622, Thermo Scientific). The positivities for the viral agents of BRD were determined by the polymerase chain reaction (PCR) process [1921]. 


\section{Statistical analysis}

Statistical analysis was performed between groups I, II and III. Tests of normality were made according to Kolmogorov-Smirnov test. If there was normal distribution for variables, an analysis of variance (ANOVA) was used for the determination of significance between groups. This was followed by a Dunnett's T3 test of multiple comparisons if variances had no homogeneity or a post hoc Tukey test if variances of groups had homogeneity. If there was no normal distribution, the Kruskal Wallis test was used for the determination of significance between all groups, followed by a multiple comparisons test to determine for which group the significance is derived from. A p-value of $<0.05$ was considered significant.

\section{RESULTS}

\section{Clinical signs}

Temperature and respiratory and pulse rates were significantly increased in the moderately and severely diseased calves compared with healthy calves $(\mathrm{P}<0.05)$ as shown in Table 1 . The calves with moderate and severe respiratory disease had clinical signs such as coughing, nasal discharge (serous, mucous or mucopurulent), dyspnoea, adventitious lung sounds, decreased appetite or anorexia, and a depressed appearance.

Table 1. Clinical examination parameters in healthy calves and in calves with bovine respiratory disease

\begin{tabular}{|c|c|c|c|}
\hline $\begin{array}{c}\text { Clinical } \\
\text { Parameters }\end{array}$ & $\begin{array}{l}\text { Group I } \\
(\mathrm{n}=18)\end{array}$ & $\begin{array}{c}\text { Group II } \\
(n=18)\end{array}$ & $\begin{array}{c}\text { Group III } \\
(n=18)\end{array}$ \\
\hline $\mathrm{T}\left({ }^{\circ} \mathrm{C}\right)$ & $\begin{array}{c}38.20(38.00-38.70) \\
38.24 \pm 0.05\end{array}$ & $\begin{array}{c}39.50(38.00-39.50)^{\mathrm{b}} \\
39.16 \pm 0.13^{\mathrm{b}}\end{array}$ & $\begin{array}{c}40.15(39.70-41.00)^{\mathrm{a}} \\
40.29 \pm 0.10^{\mathrm{a}}\end{array}$ \\
\hline R (breaths/min) & $\begin{array}{c}20(16-22) \\
19.11 \pm 0.46\end{array}$ & $\begin{array}{l}49(32-50)^{\mathrm{d}} \\
45.33 \pm 1.64^{\mathrm{d}}\end{array}$ & $\begin{array}{l}76(56-112)^{c} \\
77.83 \pm 4.28^{c}\end{array}$ \\
\hline P (beats/min) & $90.11 \pm 0.59^{\mathrm{e}}$ & $107 \pm 5.33$ & $116.22 \pm 6.62$ \\
\hline Clinical index score & & 0.34 & 0.45 \\
\hline \multicolumn{4}{|c|}{$\begin{array}{l}{ }^{\mathrm{a}} \mathrm{P}<0.05 \text { versus group I and group II; }{ }^{\mathrm{b}} \mathrm{P}<0.05 \text { versus group I; }{ }^{\mathrm{c}} \mathrm{P}<0.05 \text { versus group I and group II; } \\
\mathrm{d} P<0.05 \text { versus group I; }{ }^{\mathrm{e}} \mathrm{P}<0.05 \text { versus group II and group III } \\
\text { Group I: Healthy calves; Group II: Moderately diseased calves; Group III: Severely diseased calves; T, } \\
\text { Temperature; R: Respiratory rate (per min); P: Pulse rate (per min) } \\
\text { All the values are expressed as median (minimum - maximum) and mean } \pm \mathrm{SEM} \text { for } 18 \text { weaned calves } \\
\text { per group. }\end{array}$} \\
\hline
\end{tabular}

\section{The determined viral agents}

The PCR positivity rates for bovine herpes virus 1, bovine respiratory syncytial virus, and parainfluenza-3 were $36.1 \%, 38.9 \%$, and $25 \%$, respectively. 


\section{The results of serum biochemistry and hematologic parameters}

Serum biochemistry and hematologic parameters are given in Table 2. Serum c'TnI concentrations and $\mathrm{LDH}$ activities were significantly increased in the severely diseased calves compared with the healthy and moderately diseased calves $(\mathrm{P}<0.05)$. There was no significant difference for the serum CK-MB activity between groups. WBC counts were significantly increased in the moderately and severely diseased calves compared with the healthy calves $(\mathrm{P}<0.05)$. The percentage of lymphocytes was significantly decreased in the severely diseased calves compared with the healthy and moderately diseased calves $(\mathrm{P}<0.05)$. The percentage of neutrophils was significantly increased in the severely diseased calves compared with the healthy and moderately diseased calves $(\mathrm{P}<0.05)$. There were no significant differences for haematocrit, MCV, PLT and the percentage of monocytes, eosinophils and basophils between groups. RBC and haemoglobin levels were significantly increased in the severely diseased calves compared with the healthy and moderately diseased calves $(\mathrm{P}<0.05)$.

Table 2. Cardiac biomarkers and hematologic parameters in healthy calves and calves with bovine respiratory disease

\begin{tabular}{lccc}
\hline Parameters & $\begin{array}{c}\text { Group I } \\
(\mathbf{n}=\mathbf{1 8})\end{array}$ & $\begin{array}{c}\text { Group II } \\
\mathbf{( n = 1 8 )}\end{array}$ & $\begin{array}{c}\text { Group III } \\
(\mathbf{n}=\mathbf{1 8})\end{array}$ \\
\hline cTnI $(\mathrm{ng} / \mathrm{mL})$ & $0.02(0.01-0.04)$ & $0.02(0.01-0.04)$ & $0.1(0.04-2.84)^{\mathrm{a}}$ \\
& $0.0228 \pm 0.002$ & $0.026 \pm 0.002$ & $0.308 \pm 0.156^{\mathrm{a}}$ \\
\hline $\mathrm{CK}-\mathrm{MB}(\mathrm{U} / \mathrm{L})$ & $206.50(163-492)$ & $225(104-651)$ & $300(105-1221)$ \\
$\mathrm{LDH}(\mathrm{U} / \mathrm{L})$ & $232.22 \pm 17.54$ & $309.67 \pm 41.05$ & $427.11 \pm 26.28$ \\
\hline $\mathrm{WBCs}\left(\mathrm{x} 10^{3} / \mu \mathrm{l}\right)$ & $658.61 \pm 28.97$ & $677.94 \pm 62.16$ & $905.39 \pm 54.17^{\mathrm{b}}$ \\
\hline Lymphocytes $(\%)$ & $6.88 \pm 0.21$ & $10.69 \pm 0.36^{\mathrm{d}}$ & $20.52 \pm 2.0^{\mathrm{c}}$ \\
\hline Neutrophils $(\%)$ & $60.82 \pm 2.58$ & $58.92 \pm 3.31$ & $41.57 \pm 3.49^{\mathrm{e}}$ \\
\hline Monocytes $(\%)$ & $32.11 \pm 2.47$ & $34.54 \pm 3.23$ & $53.08 \pm 3.86^{\mathrm{f}}$ \\
& $1.05(0.50-9.50)$ & $1.80(0.50-9.90)$ & $1.10(0.60-9.10)$ \\
Eosinophils $(\%)$ & $3.08 \pm 0.78$ & $4.07 \pm 0.897$ & $3.36 \pm 0.836$ \\
& $1.75(0.50-14.30)$ & $1.90(0.40-6.40)$ & $1.25(0.40-9.80)$ \\
Basophils $(\%)$ & $3.88 \pm 1.086$ & $2.39 \pm 0.44$ & $1.91 \pm 0.51$ \\
\hline RBCs $\left(\mathrm{x} 10^{6} / \mu \mathrm{L}\right)$ & $0.10(0.00-0.50)$ & $0.10(0.00-0.30)$ & $0.05(0.00-0.40)$ \\
\hline Haemoglobin $(\mathrm{g} / \mathrm{dL})$ & $0.12 \pm 0.034$ & $0.08 \pm 0.019$ & $0.08 \pm 0.026$ \\
\hline Haematocrit $(\%)$ & $8.37 \pm 0.47$ & $8.28 \pm 0.38$ & $9.97 \pm 0.52^{\mathrm{g}}$ \\
\hline MCV $(\mathrm{fL})$ & $9.82 \pm 0.32$ & $9.05 \pm 0.37$ & $10.52 \pm 0.48^{\mathrm{h}}$ \\
\hline PLT $\left(\mathrm{x} 10^{3} / \mu \mathrm{L}\right)$ & $33.11 \pm 1.29$ & $29.26 \pm 1.25$ & $33.01 \pm 1.64$ \\
\hline
\end{tabular}

${ }^{a} \mathrm{P}<0.05$ versus group I and group II; ${ }^{\mathrm{b}} \mathrm{P}<0.05$ versus group I and group II; ${ }^{\mathrm{c}} \mathrm{P}<0.05$ versus group I and group II; ${ }^{\mathrm{d}} \mathrm{P}<0.05$ versus group I and group III; ${ }^{\mathrm{e}} \mathrm{P}<0.05$ versus group I and group II; ${ }^{\mathrm{f}} \mathrm{P}<0.05$ versus group I and group II; ${ }^{\mathrm{P}}<0.05$ versus group I and group II; ${ }^{\mathrm{h}} \mathrm{P}<0.05$ versus group I and group II Group I: Healthy calves; Group II: Moderately diseased calves; Group III: Severely diseased calves; cTnI: Cardiac troponin I; CK-MB: Creatine kinase-myocardial band; LDH: Lactate dehydrogenase; WBC: White blood cells; RBC: Red blood cells; MCV: Mean corpuscular volume; PLT: Platelet.

All the values are expressed as median (minimum - maximum) and mean \pm SEM for 18 weaned calves per group. 


\section{DISCUSSION}

This study assessed the enzymes cTn I, CK-MB, and LDH for the detection of possible myocardial damage secondary to moderate and severe respiratory disease in weaned calves. Increased serum cTnI concentrations were determined in the weaned calves with severe BRD. However, there was no increase for the serum cTnI concentration in the moderately diseased calves.

Cardiac troponin assays designed for human use are a sensitive and specific marker for the determination of myocardial degeneration and necrosis in animals [15,22]. Some biomarkers, such as CK-MB and $\mathrm{LDH}$, do not come close to the cardiac troponin biomarker in the evaluation of myocardial injury. LDH and CK-MB, which are found in skeletal muscle and heart, do not have any tissue sensitivity and specificity. Additionally, their cardiac activities are lower than the total enzyme activities $[10,12]$. In the study, cTnI concentrations and LDH activities were significantly increased in the severely diseased calves compared with the healthy and moderately diseased calves. Furthermore, there was no significant difference for CK-MB between the studied groups. This study suggests that myocardial myocytes might be affected because of increased serum cTnI in severe BRD in weaned calves.

The viral and bacterial agents of pneumonia can cause myocarditis in humans [23]. Sporadic myocarditis or myocardial necrosis in patients with severe influenza B virus $[24,25]$ and significant frequency of bacterial pneumonia in patients with cardiac injury [16] have also been reported. Hoar et al. [26] have reported myocarditis findings consistent with $H$. somnus in calves with bronchopneumonia that died after the treatment period. In the present study, we detected the PCR positivity rate for bovine herpes virus 1 as $36.1 \%$, bovine respiratory syncytial virus as $38.9 \%$, and parainfluenza-3 as $25 \%$, from the viral agents of BRD in the diseased groups.

Increased serum cardiac troponin levels have been found in a wide variety of clinical conditions such as myocarditis, non-ischemic cardiac disorders, atrial fibrillation, hypovolemia, sepsis, endotoxemia [27], ruminal acidosis [28], theileriosis [14] and M. bovis-induced pneumonia [29]. Toxic effects from bacterial endotoxins, cardiac depressant effects from cytokines, cardiac oxygen demands exceeding supplies, which are developed with inflammation, ventilation-perfusion mismatches in acute pneumonia, depression of myocardial contractility, catecholamine release, and tachycardia may cause increased serum cardiac troponin levels [6,30]. In these conditions increased serum cardiac troponin levels are linked with the release of free cytosolic or structurally bound troponin [12]. In this study, serum c'TnI concentrations were increased in the severely diseased calves more than in the moderately diseased calves. Therefore, inflammation, tachycardia, hypoxia, and cytokines involved in the pathogenesis of BRD [1] may have been more severe in the severely diseased calves than in the moderately diseased calves; this is consistent with the clinical index scores and significantly increased WBC counts. 
A greater severity of pneumonia can lead to cardiac complications [6]. The occurrence of tachycardia caused by hypoxemia in pneumonia cases is expressed by an increase in the sympathetic activity, causing an increased myocardial oxygen demand [26]. Moammar et al. [31] have noted that decreased blood oxygen levels may play a role in acute myocardial damage in patients with community-acquired pneumonia. Furthermore, Corrales-Medina et al. [26] reported that cardiac arrhythmias occur as a complication of acute pneumonia. In the present study, increased pulse rates were found in the moderately and severely diseased calves but respiratory rates were significantly increased only in calves with severe BRD compared to calves with moderate BRD.

Complete blood cells are variable and nonspecific in BRD. Hematology may show neutrophilia, neutropenia or be normal in BRD and may be associated with a different etiology and dependent upon whether the disease is in the acute or chronic stage [3]. In this study, neutrophilia and lymphopenia were found in the severely diseased calves. There were no significant differences for haematocrit, MCV, PLT or the percentages of monocytes, eosinophils and basophils between groups. RBC and haemoglobin levels were significantly increased in the severely diseased calves compared with the healthy and moderately diseased calves.

\section{CONCLUSIONS}

The result of this study suggests that severe BRD causes increased serum cTnI concentrations in weaned calves. Prognosis for the possible cardiac complications in calves with severe BRD may be monitored by serum cTnI measurements.

\section{REFERENCES}

1. Panciera RJ, Confer AW: Pathogenesis and pathology of bovine pneumonia. Vet Clin Food Anim 2010, 26: 191-214.

2. Step DL, Confer AW: Chapter 41: Mannheimia haemolytica- and pasteurella multocidainduced bovine pneumonia. In: Current Veterinary Therapy: Food Animal Practice, Fifth Volume, Saunders; 2009, 164-194.

3. Divers TJ: Chapter 4: Respiratory diseases. In: Rebbun's Diseases of Dairy Cattle, Second Edition, Saunders; 2008, 79-127.

4. Mosier D: Review of BRD pathogenesis: the old and the new. Anim Health Res Rev 2014, 15: 166-168.

5. Babuin L, Jaffe AS: Troponin: the biomarker of choice for the detection of cardiac injury. C M A J 2005, 173: 1191-1201.

6. Chang CL, Mills GD, Karalus NC, Jennings LC, Laing R, Murdoch DR, Chambers ST, Vettise D, Tuffery CM, Hancox RJ: Biomarkers of cardiac dysfunction and mortality from community-acquired pneumonia in adults. PLoS ONE 2013, 8: e62612.

7. Tothova C, Nagy O, Kovac G: The serum protein electrophoretic pattern and acute phase proteins concentrations in calves with chronic respiratory diseases. Acta Veterinaria (Beograd) 2013, 63: 473-486. 
8. Hoffmeister HM, Ehlers R, Büttcher E, Steinmetz A, Kazmaier A, Kazmaier S, Helber U, Szabo S, Beyer ME, Seipel L: Relationship between minor myocardial damage and inflammatory acute-phase reaction in acute coronary syndromes. J Thrombolysis 2003, 15 : 33-39.

9. O'Brien PJ: Blood cardiac troponin in toxic myocardial injury: archetype of a translational, safety biomarker. Expert Rev Mol Diagn 2006, 6: 685-702.

10. O’Brien PJ: Cardiac troponin is the most effective translational safety biomarker for myocardial injury in cardiotoxicity. Toxicol 2008, 245: 206-218.

11. Serra M, Papakonstantinou S, Adamcova M, O’Brien PJ: Veterinary and toxicological applications for the detection of cardiac injury using cardiac troponin. Vet J 2010, 185: 50-57.

12. Wells SM, Sleeper M: Cardiac troponins. J Vet Emerg Crit Care 2008, 18: 235-245.

13. Mellanby RJ, Henry JP, Cash R, Ricketts SW, Bexiga R, Truyers I, Mellor DJ: Serum cardiac troponin I concentrations in cattle with cardiac and non-cardiac disorders. J Vet Intern Med 2009, 23: 926-930.

14. Fartashvand M, Nadalian MG, Sakha M, Safi S: Elevated serum cardiac troponin I in cattle with theileriosis. J Vet Intern Med 2013, 27: 194-199.

15. Leonardi F, Passeri B, Fusari A, De Razza P, Beghi C, Lorusso R, Corradi A, Botti P: Cardiac troponin I (cTnI) concentration in an ovine model of myocardial ischemia. Res Vet Sci 2008, 85: 141-144.

16. Paddock CD, Liu L, Denison AM, Barlett JH, Holman RC, DeLeon-Carnes M, Emery SL, Drew CP, Shieh W, Uyeki TM, Zaki SR: Myocardial injury and bacterial pneumonia contribute to the pathogenesis of fatal influenza B virus infection. J I D 2012, 205: 895-905.

17. Balmer TV, Williams P, Selman IE: Comparison of carprofen and flunixin meglumine as adjunctive therapy in bovine respiratory disease. Vet J 1997, 154: 233-241.

18. O’Brien PJ, Landt Y, Ladenson JH: Differential reactivity of cardiac and skeletal muscle from various species in a cardiac troponin I immunoassay. Clin Chem 1997, 43: 2333-2338.

19. Lata J, Kanani AN, Purohit JH, Joshi CG, Rank DN, Kumar V, Jain VK: Detection of bovine herpesvirus 1 (BHV-1) infection in semen of indian breeding bulls by polymerase chain reaction and its characterization by DNA sequencing. Buffalo Bulletin 2009, 28: 7684.

20. Maidana SS, Lomonaco PM, Combessies G, Craig MI, Diodati J, Rodriguez D, Parreño V, Zabal O, Konrad JL, Crudelli G, Mauroy A, Thiry E, Romera SA: Isolation and characterization of bovine parainfluenza virus type 3 from water buffaloes (Bubalus bubalis) in Argentina. BMC Vet Res 2012, 8: 83.

21. Vilcek S, Elvander M, Ballagi-Pordány A, Belák S: Development of nested PCR assays for detection of bovine respiratory syncytial virus in clinical samples. J Clin Microbiol 1994, 32: 2225-2231.

22. Gunes V, Ozcan K, Citil M, Onmaz AC, Erdogan HM: Detection of myocardial degeneration with point-of-care cardiac troponin assays and histopathology in lambs with white muscle disease. Vet J 2010, 184: 376-378.

23. Corrales-Medina VF, Suh KN, Rose G, Chirinos JA, Doucette S, Cameron DW, Fergusson DA: Cardiac complications in patients with community-acquired pneumonia: a systematic review and meta-analysis of observational studies. PLoS Med 2011, 8: e1001048.

24. Craver RD, Sorrells K, Gohd R: Myocarditis with influenza B infection. Pediatr Infect Dis J 1997, 16: 629-30. 
25. Tabbutt S, Leonard M, Godinez RI, Sebert M, Cullen J, Spray TL, Friedman D: Severe influenza B myocarditis and myositis. Pediatr Crit Care Med 2004, 5: 403-6.

26. Hoar BR, Jelinski MD, Ribble CS, Janzen ED, Johnson JC: A comparison of the clinical field efficacy and safety of florfenicol and tilmicosin for the treatment of undifferentiated bovine respiratory disease of cattle in western Canada. Can Vet J 1998, 39: 161-166.

27. Peek SF, Apple FS, Murakami MA, Crump PM, Semrad SD: Cardiac isoenzymes in healthy Holstein calves and calves with experimentally induced endotoxemia. Can Vet J 2008, 72: 356-361.

28. Kirbas A, Baydar E, Kandemir FM, Dorman E, Kizil O, Yildirim BA: Evaluation of serum cardiac troponin I concentration in sheep with acute ruminal lactic acidosis. Vet Arhiv 2014, 84: 355-364.

29. Fraser BC, Anderson DE, White BJ, Miesner MD, Lakritz J, Amrine D, Mosier DA: Association of various physical and blood analysis variables with experimentally induced Mycoplasma bovis pneumonia in calves. Am J Vet Res 2014, 75: 200-207.

30. Varga A, Angelos JA, Graham TW, Chigerwe M: Preliminary investigation of cardiac troponin I concentration in cows with common production diseases. J Vet Intern Med 2013, 26: 1613-1621.

31. Moammar MQ, Ali MI, Mahmood NA, DeBari VA, Khan MA: Cardiac troponin I levels and alveolar-arterial oxygen gradient in patients with community-acquired pneumonia. Heart, Lung \& Circulation 2010, 19: 90-92.

\section{KONCENTRACIJA SRČANOG TROPONIONA-I KOD ZALUČENE TELADI SA RESPIRATORNIM SINDROMOM}

HANEDAN Basak, KIRBAS Akin, DORMAN Emrullah, TIMURKAN Mehmet Ozkan, KANDEMIR Fatih Mehmet, ALKAN Omer

Cilj studije je bio da se proceni koncentracija serumskog srčanog troponina-I (c'TnI) kod zalučene teladi sa umerenim ili teškim bovinim respiratornim sindromom. Osamnaest zdravih zalučenih teladi (grupa I), 18 zalučenih teladi sa umerenim respiratornim sindromom (grupa II) i 18 zalučenih teladi sa teškim oblikom respiratornog sindroma (grupa III) je bilo uključeno u ovu studiju. Klinički znaci kao i težina respiratornog sindroma bili su određeni pomoću kliničkih indeksa. Broj krvnih ćelija, srčani biomarkeri, kao što su serumska koncentracija c'TnI i kreatin-kinaza (CK-MB) i aktivnost laktat dehidrogenaze (LDH) bili su određeni u svakoj od oglednih grupa. Temperatura, frekvenca disanja i srčanog pulsa bili su signifikantno povišeni $(\mathrm{P}<0,05)$ kod teladi sa umerenim i teškim bovinim respiratornim sindromom u odnosu na zdravu telad. Vrednosti koncentracije serumskog cTnI i aktivnosti LDH bile su signifikantno povišene $(\mathrm{P}<0,05)$ kod teladi sa teškim oblikom respiratornog sindroma u odnosu na zdravu telad i telad sa umerenim oblikom bolesti. Takode je ustanovljen signifikantan porast broja leukocita kod teladi sa umerenim i teškim respiratornim sindromom, kao i limfopenija i neutrofilija kod teladi sa teškim oblikom respiratornog sindroma. Dobijeni rezultati sugerišu da težak oblik respiratornog oboljenja dovodi do povećanja koncentracije serumskog c'TnI kod zalučene teladi. 